\title{
Android Trainer Wawancara Pekerjaan Dalam Bahasa Inggris Menggunakan Audio Visual Dengan Metode Prototype
}

\author{
Dentik Karyaningsih $^{[1]^{*}}$, Diki Susandi ${ }^{[2]}$, Erina Juwita ${ }^{[3]}$ \\ Program Studi Informatika, Fakultas Teknologi Informasi \\ Universitas Serang Raya \\ Jl. Raya Cilegon No.Km. 5, Taman, Drangong, Kec. Taktakan, Kota Serang, Banten \\ karya.tiek@gmail.com ${ }^{[1]}$, unsera.diky@gmail.com ${ }^{[2]}$, erinajuwita099@gmail.com ${ }^{[3]}$
}

\begin{abstract}
Job competition is getting tougher after the implementation of the ASEAN Economic Community. Prospective workers are required to have competence at work and be skilled at communicating using international languages, especially English. Based on the results of the questionnaire on 100 data samples using google form, there are as many as $\mathbf{5 0 \%}$ having difficulty when interviewing using English. So this study is proposed to improve English pronunciation skills during job interviews. Android Trainer is self-training using the Android Platform. It is designed using Google Speech API and Speech Recognition Technology. It is displayed using Audio Visual and the development method uses the Prototype method. The result of this research is the Android Trainer which is a smart solution to make it easier to practice independently at any time. So that it can improve English pronunciation skills. This is useful when going through the interview process using English at various types of companies during the employee recruitment process.
\end{abstract}

Keywords-Android, Trainer, interview, speech, Voice

Abstrak- Persaingan pekerjaan semakin ketat setelah diberlakukan Masyarakat Ekonomi ASEAN. Calon tenaga kerja diharuskan memiliki kompetensi pada pekerjaan dan terampil berkomunikasi menggunakan bahasa internasional, khususnya Bahasa Inggris. Berdasarkan hasil kuisioner atas 100 sampel data dengan menggunakan google form, terdapat sebanyak $50 \%$ mengalami kesulitan saat wawancara menggunakan Bahasa Inggris. Maka penelitian ini diusulkan untuk meningkatkan kemampuan pengucapan Bahasa Inggris pada saat wawancara kerja. Android Trainer adalah pelatihan mandiri menggunakan Platform Android. Ini dirancang dengan memanfaatkan Google Speech API dan Teknologi Pengenalan Suara. Ini ditampilkan menggunakan Audio Visual dan metode pengembangan menggunakan metode Prototipe. Hasil penelitian ini adalah Android Trainer yang merupakan solusi cerdas untuk memudahkan berlatih secara mandiri kapan saja. Sehingga dapat meningkatkan kemampuan pengucapan Bahasa Inggris. Ini berguna saat melewati proses wawancara menggunakan Bahasa Inggris pada beragam jenis perusahaan saat proses perekrutan karyawan.

Kata Kunci-Android, Trainer, wawancara, speech, Voice

\section{PENDAHULUAN}

Persaingan dalam mendapatkan pekerjaan di era diberlakukanya Masyarakat Ekonomi ASEAN (MEA) semakin ketat. Para calon tenaga kerja dituntut tidak hanya memenuhi kriteria mahir dalam bidang pekerjaannya tetapi juga harus memiliki keterampilan dalam berkomunikasi menggunakan bahasa internasional yaitu Bahasa Inggris. Dalam melakukan seleksi, sebuah perusahaan menetapkan keterampilan berkomunikasi dalam Bahasa Inggris sebagai salah satu syarat penerimaan. Disinilah pentingnya melakukan latihan berkomunikasi dalam Bahasa Inggris terutama pada saat wawancara kerja [1].

Mengantisipasi kesulitan-kesulitan yang dihadapi oleh para kandidat tenaga kerja dalam wawancara kerja, perlu adanya sebuah usaha untuk membantu mereka. Berdasarkan hasil survey kuisioner menggunakan google form dengan sampel 100 data, bahwa yang menjadi kesulitan saat menghadapi wawancara menggunakan Bahasa Inggris yaitu $50 \%$ pengucapan Bahasa Inggris, menghapal Kosa kata $42 \%$ dan $8 \%$ untuk alasan yang lain dan solusi terbaik untuk mengatasi masalah tersebut menunjukan $21 \%$ mengikuti kursus/pelatihan, $29 \%$ belajar mandiri dan 50\% dibuatkannya sistem aplikasi android.

Beberapa Penelitian yang sudah dilakukan diantaranya membuat profil diri dalam bentuk CV secara daring dan konvensional juga dalam bentuk media sosial profesional. Selain itu, peserta juga membuat surat lamaran kerja secara konvensional dan elektronik serta mendapatkan simulasi praktek wawancara kerja dalam Bahasa Inggris [2]. Penelitian berikutnya dilakukan dalam bentuk workshop, setelah diberikan pengetahuan tentang pentingnya pengetahuan tehnik wawancara, cara berkomunikasi yang baik dan benar, peserta melakukan simulasi wawancara menggunakan Bahasa Indonesia dan Bahasa Inggris [3]. Hasil Penelitian berikutnya adalah Alat Bantu Belajar English Conversatiation Berbasis Android dengan Menerapkan Voice Recognition adalah sebuah aplikasi belajar Bahasa Inggris berbasis smartphone 
android english teacher yang memungkinkan pengguna dapat belajar Bahasa Inggris secara digital dengan mudah kapanpun dan dimanapun [4] dan "VR Job Interview Simulator: Where Virtual Reality Meets Artificial Intelligence for Education" menyajikan VR Job, sebuah aplikasi yang mengusulkan cara pelatihan inovatif untuk wawancara. Dengan menggabungkan keunggulan berbagai teknologi, seperti virtual reality dan chatbot, aplikasi kami menciptakan cara interaktif untuk membantu teknisi perangkat lunak melatih untuk wawancara mereka. Teknik pengenalan emosi juga disertakan, membantu memberikan umpan balik yang akurat bagi pengguna [5]. Penelitian sebelumnya adalah melakukan pelatihan wawancara Bahasa Inggris dengan media-media untuk mempermudah dalam Latihan Wawancara pekerjaan. Penelitian ini adalah suatu aplikasi Trainer wawancara pekerjaan menggunakan audio visual berbasis aplikasi android untuk wawancara pekerjaan.

Penelitian ini dilakukan untuk memberikan Trainer wawancara menggunakan Bahasa Inggris pada saat wawancara pekerjaan. Bagi perusahahaan multinasional diwilayah Propinsi Banten beberapa bagian pada posisi diperusahaan perekrutan pekerjaan menggunakan Bahasa Inggris sehingga para pencari kerja harus dapat berkomunikasi dengan Bahasa Inggris, sehingga Trainer wawancara Bahasa Inggris berbasis android menggunakan Audio Visual yang mudah dipahami dan lebih efektif ini sangat dibutuhkan oleh para pencari kerja agar dapat Menjadi media pelatihan mandiri untuk meningkatkan kemampuan verbal dalam mengucapkan Bahasa Inggris saat wawancara kerja dimanapun dan kapanpun.

Bahasa Inggris adalah bahasa global yang sangat berperan dalam intreraksi dan komunikasi global seiring dengan kemajuan dan persaingan globalisasi. Selain daripada itu, Bahasa Inggris telah menjadi satu kata kunci yang sanggup menggenggam segala aspek, baik itu bisnis, politik, sosial, maupun budaya. Dengan kata lain, kemampuan dalam berbahasa Inggris dapat pula dijadikan sebagai investasi [6].

Wawancara kerja menjadi tahap khusus buat yang ingin mendapatkan pekerjaan impian. Ada banyak sekali cara yang dilakukan pencari kerja agar sukses, mulai dari mempelajari budaya perusahaan, bisnis, hingga pertanyaan yang biasa dilontarkan oleh pewawancara [7]. Android Trainer wawancara pekerjaan dalam Bahasa Inggris menggunakan Audio Visual adalah suatu aplikasi Trainer yang menyediakan latihan-latihan pertanyaan seputar wawancara pekerjaan menggunakan Bahasa Inggris baik teks maupun suara, serta koreksi pada pengucapan Bahasa Inggris dan terdapat evaluasi penilaian dalam latihan wawancara kerja menggunakan Bahasa Inggris. Aplikasi ini adalah untuk mengatasi kesulitan pengucapan untuk orang yang akan melakukan wawancara pekerjaan dalam Bahasa Inggris dengan menerapkan teknologi Voice Recognition dengan menggunakan Audio Visual sebagai penyampainnya didalam Aplikasi Android.

Trainer wawancara pekerjaan berbasis Android dibangun dengan menggunakan Software Kotlin, Voice Recognition Goole Speech API dan Database MySQL.

\section{METODOLOGI PENELITIAN}

Metode penelitian yang digunakan adalah metode eksperimen yaitu Pengumpulan data, Analisis, Design, Implementasi, Evaluasi.

\section{A. Pengumpulan Data}

Pengumpulan data dilakukan dengan cara melakukan studi literatur pada buku-buku, jurnal dan artikel, serta melakukan wawancara melalui penyebaran kueisioner menggunakan Google Form yang disebarkan kepada calon pekerja dengan menyebarkan kepada para alumni Universitas Serang Raya dan Balai Latihan kerja sebanyak 100 orang Seputar Pertanyaan dan Jawaban dari hasil google form yang dilakukan kepada pegawai yang sudah mendapatkan wawancara pekerjaan menggunakan Bahasa pada perusahaan multinasional diwilayah Propinsi Banten. Pengambilan data dilakukan pada tanggal 4-10 September 2020.

\section{B. Analisis}

Android trainer wawancara pekerjaan dalam bahasa inggris menggunakan audio visual adalah suatu aplikasi yang dirancang untuk memberikan pelatihan wawancara dengan Bahasa Inggris secara mandiri. Analisis terhadap pengumpulan data yang ada dilakukan dengan menggunakan metode analisis kuantitatif. Hasil analisa kuantitatif didapat bahwa terdapat beberapa kesulitan bagi para pelamar pekerjaan seputar pertanyaan pada saat wawancara, jawaban yang harus dijawab pada saat wawancara kerja, serta pengucapan Bahasa Inggris yang benar. Hasil tersebut menjadi dasar pengembangan aplikasi android trainer.

\section{Design}

Pengembangan perancangan yang dibangun pada aplikasi trainer wawancara pekerjaan dalam Bahasa Inggris menggunakan Audio Visual berbasis android menggunakan UML (Unified Modeling Language). UML (Unified Modeling Language) adalah bahasa pemodelan untuk sistem atau perangkat lunak yang berparadigma "berorientasi objek" [8].

\section{1) Use Case Diagram}

Use Case diagram menggambarkan fungsionalitas yang diharapkan dari sebuah sistem. Sebuah Use Case mempresentasikan sebuah interaksi antara aktor dengan sistem. Digunakan untuk memodelkan suatu sistem atau perangkat lunak dilihat dari sisi pengguna yang ada pada sistem. Use Case pada dasarnya merupakan unit yang diekspresikan sebagai transaksi-transaksi yang terjadi antara aktor dan system [11]. 


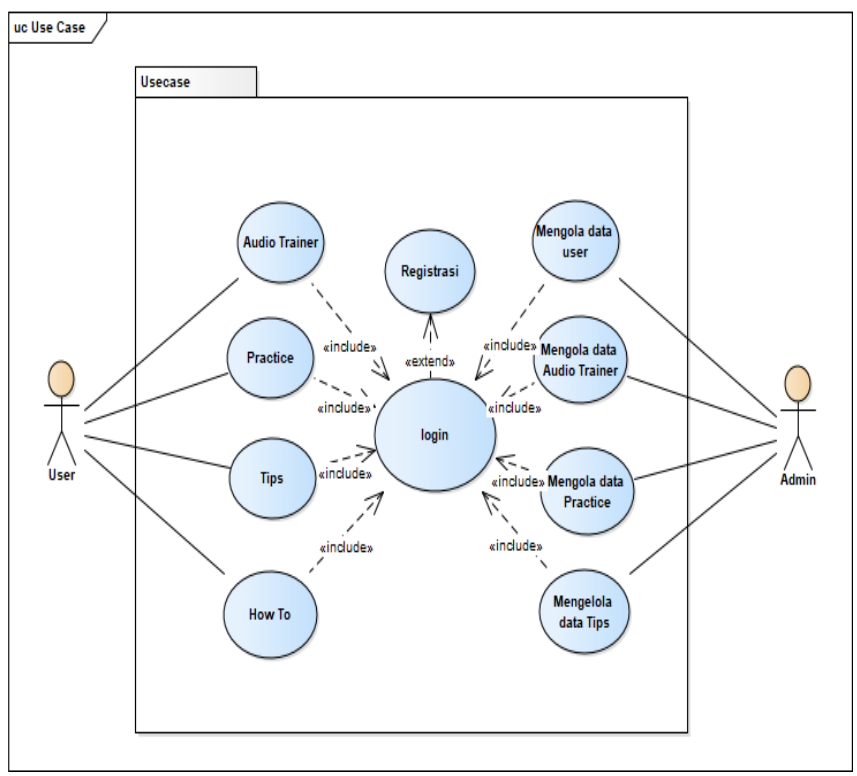

Gambar 1. Use Case Diagram Aplikasi Android Trainer Wawancara

Use Case Diagram aplikasi terdapat dua aktor yaitu User dan Admin. Untuk actor user ada beberapa use case yaitu Audio Trainer, practice, tips dan how to sedangkan actor admin ada use case mengola data user, mengola data Audio Trainer, mengola data practice, dan mengola data tips .user dan admin tentunya harus melakukan login untuk bisa mengakses aplikasi tersebut dan untuk login harus melakukan registrasi terlebih dahulu.

\section{2) Class Diagram}

Class diagram adalah diagram untuk menggambarkan class class yang ada pada aplikasi Android Trainer wawancara pekerjaan dalam Bahasa Inggris menggunakan Audio Visual, terdapat beberapa class yaitu AudioTariner, Practice, Tips, User dan Group seperti pada Gambar 2.

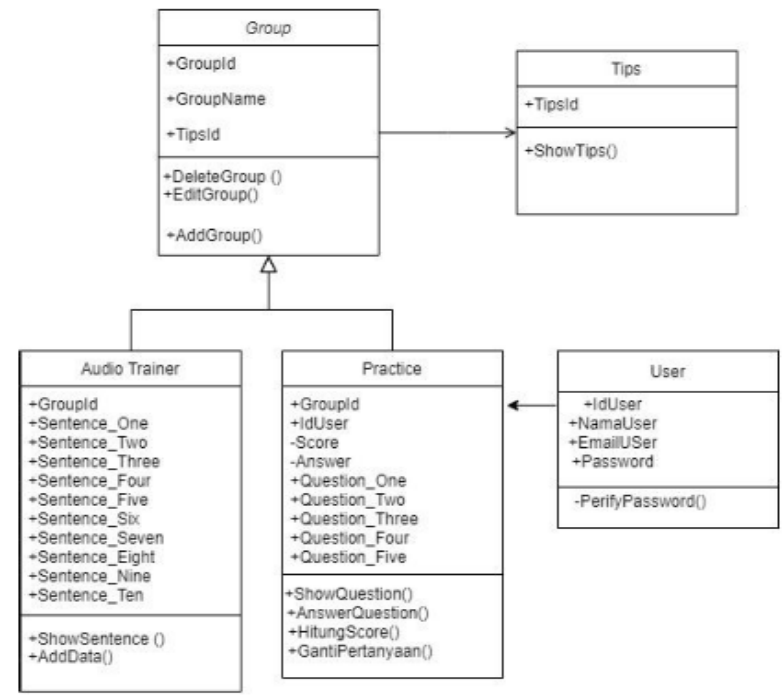

Gambar 2. Class Diagram

\section{3) Struktur Menu}

Struktur menu merupakan sebuah bentuk umum rancangan program yang bertujuan untuk membantu pengguna dalam menyelesaikan sebuah tugas. Struktur menu yang digunakan dalam Aplikasi Android Trainer Wawancara Pekerjaan dalam Bahasa Inggris Menggunakan Audio Visual terdapat 4 menu utama yaitu Audio Trainer dan submenu, Practice dan submenu Tips dan submenu dan How to seperti pada Gambar 3.

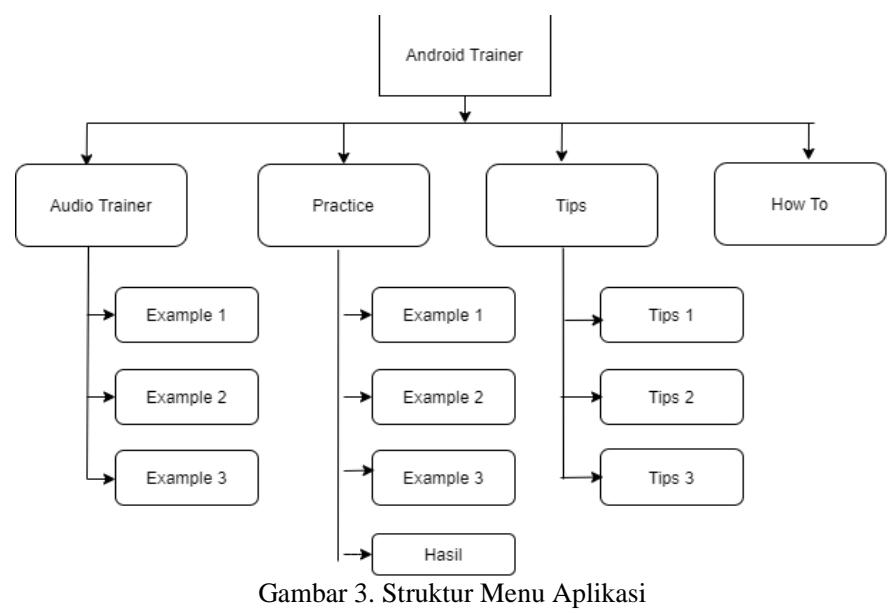

Metode pengembangan sistem yang digunakan pada penelitian ini adalah metode Prototype. Metode Prototype adalah merupakan metode pengembangan perangat lunak, yang berupa model fisik kerja sistem dan berfungsi sebagai versi awal dari system [9]. Model prototyping yaitu Berfokus pada penyajian dari aspek aspek perangkat lunak tersebut yang akan nampak bagi pemakai. Tahapan model pengembangan prototyping ini digambarkan pada Gambar 4.

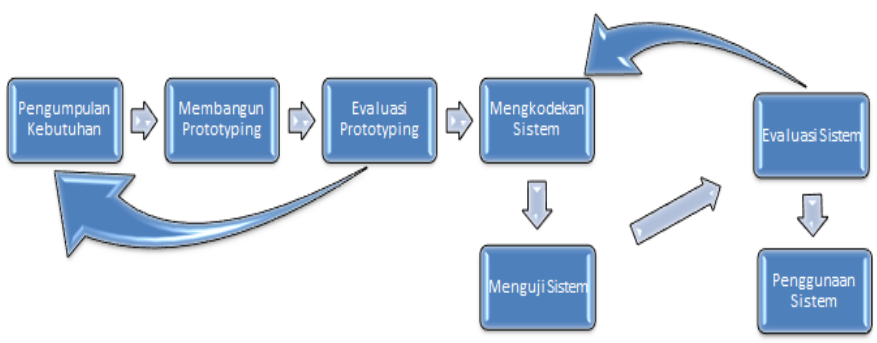

Gambar 4. Model Pengembangan Prototyping

Aplikasi trainer wawancara pekerjaan dalam bahasa inggris menggunakan audio visual berbasis android software yang digunakan kotlin, voice recognition google speech API dan database MySQL.

\section{Implementasi}

Aplikasi trainer wawancara pekerjaan pada tahap implementasi sistem diaplikasikan pada para pencari kerja diwilayah Propinsi Banten.

\section{E. Evaluasi}

Pengujian pada aplikasi trainer wawancara pekerjaan adalah menggunakan ujicoba black box testing. black box 
testing dimana perangkat lunak tidak di uji dari desain dan kode program namun di uji dari segi spesifikasi fungsional. Pengujian ini bertujuan untuk mengetahui fungsi-fungsi yang ada pada perangkat lunak apakah sudah sesuai dengan spesifikasi yang dibutuhkan atau belum [10].

\section{HASIL DAN PEMBAHASAN}

Penelitian ini menghasilkan suatu Aplikasi Android Trainer wawancara pekerjaan

\section{A. Aplikasi Android Trainer Wawancara Pekerjaan}

Aplikasi yang telah dirancang menggunakan software android studio. Untuk mengaksess aplikasi android trainer ini, pengguna melakukan instalasi program terlebih dahulu melalui Playstore dan aplikasi android trainer ini hanya bisa dijalankan pada sistem yang berbasis android saja. Untuk dapat mengakses aplikasi, pengguna harus terkoneksi dengan akses Internet.

\section{1) Halaman Utama Aplikasi}

Untuk akses halaman menu utama user/pengguna sudah melakukan register kemudian login ke dalam aplikasi. Halaman menu utama terdapat menu Audio Trainer sebagai menu media untuk mendengarkan Audio, menu Practice sebagai media untuk melatih pengucapan, menu tips untuk informasi tips seputar wawancara pekerjaan dan menu how to untuk petunjuk menggunakan aplikasi, seperti Gambar 5.

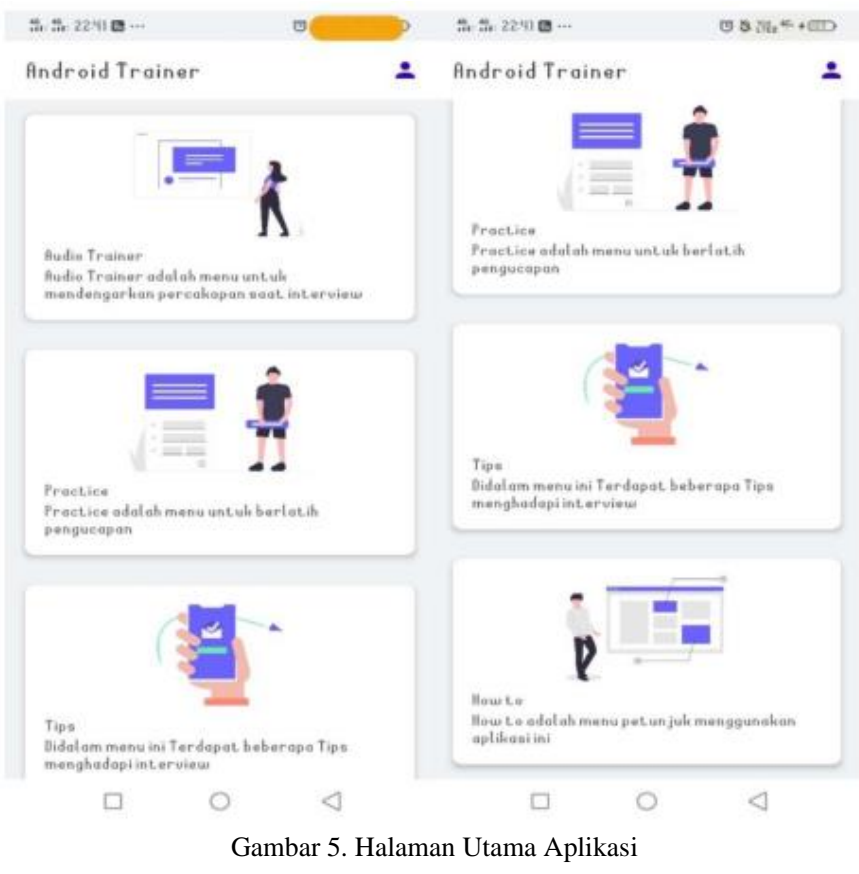

\section{2) Halaman Audio Trainer}

Halaman Audio Trainer yaitu sebagai sarana mendengarkan Audio percakapan saat wawancara pekerjaan yang didalamnya terdapat sub menu Audio Trainer yang bisa dipilih pengguna, sebagai contoh pengguna memilih greeting dan akan tampil tampilan percakapan seputar wawancara yang bisa di dengarkan oleh pengguna secara berulang ulang, seperti Gambar 6.

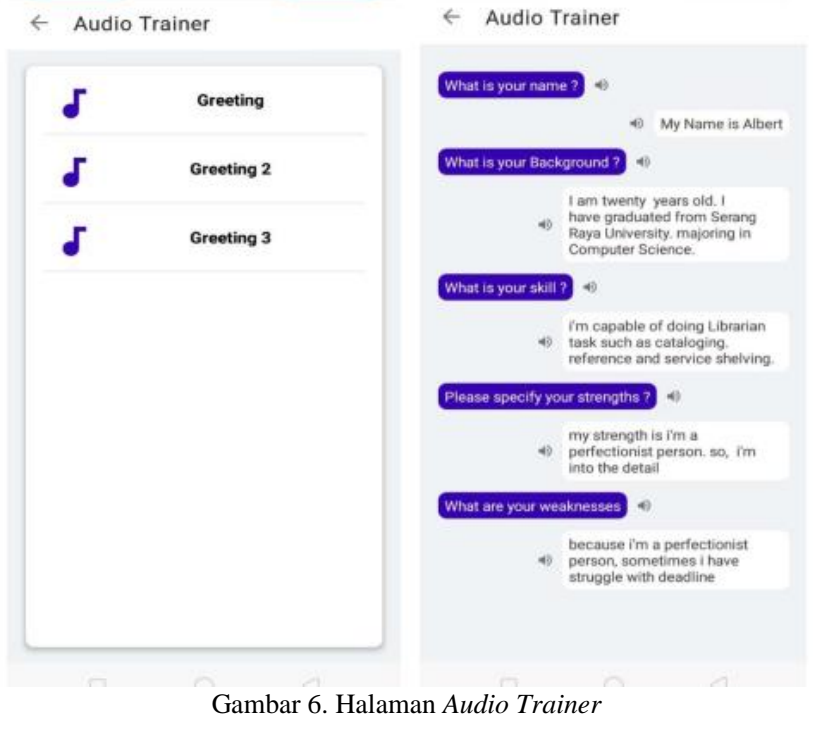

\section{3) Halaman Practice}

Halaman practice yaitu sebagai sarana melatih pengucapan saat wawancara pekerjaan, yang didalamnya terdapat sub menu practice yang bisa dipilih pengguna, sebagai contoh pengguna memilih greeting kemudian akan muncul tampilan step by step percakapan seputar wawancara dan pengguna bisa merekam suara untuk menyesuaikan pengucapannya dan akan muncul presentase hasil pengucapannya seperti Gambar 7 .
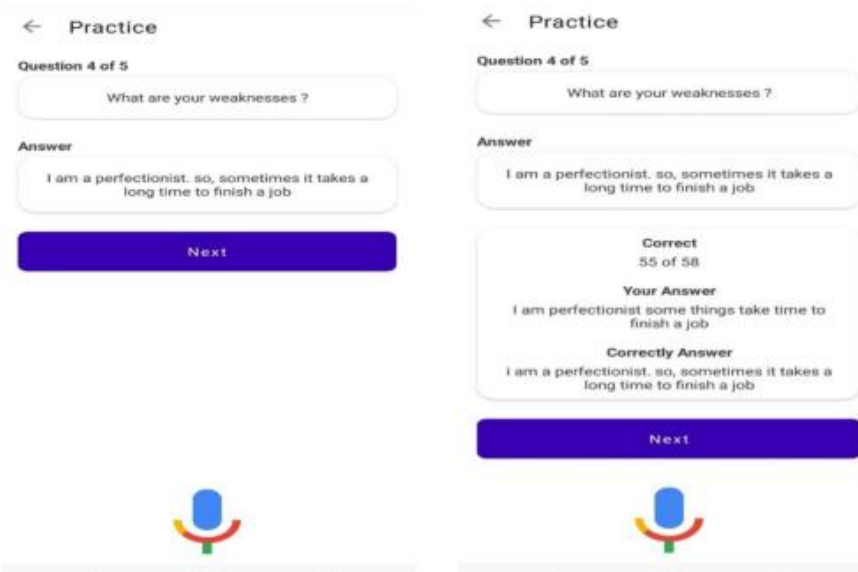

Gambar 7. Halaman Practice

\section{4) Halaman Tips}

Halaman tips yaitu halaman menu tips yang berisikan berbagai informasi tips saat menghadapi wawancara, seperti tips hal yang tidak boleh dilakukan saat wawancara dan akan menampilkan informasi yang dipilih seperti Gambar 8. 


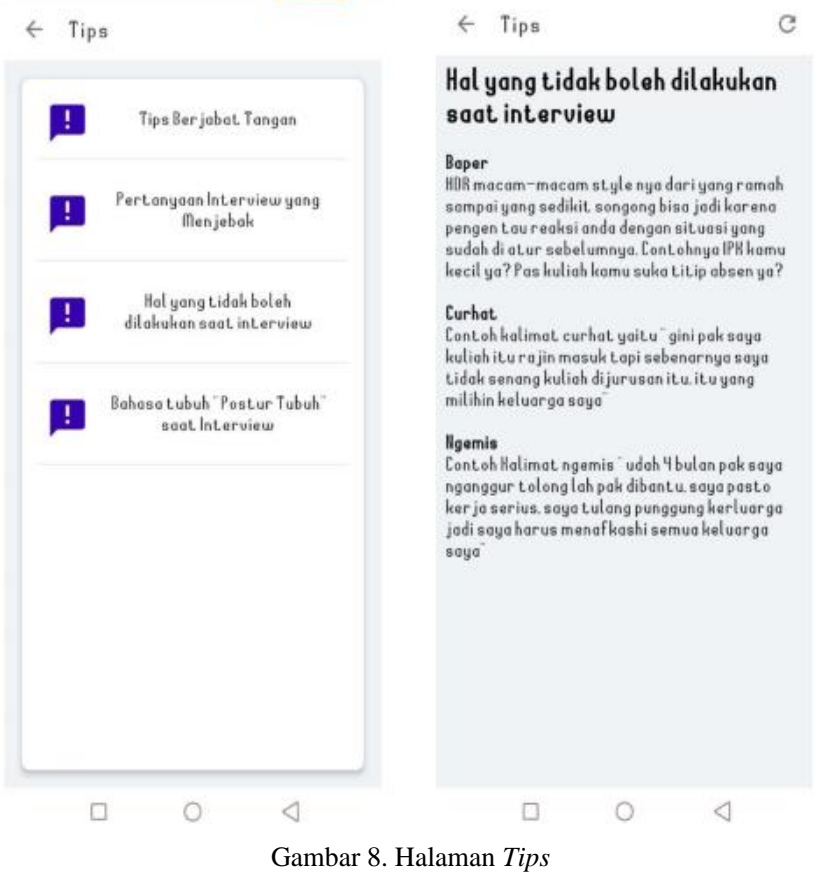

\section{5) Halaman How To}

Halaman how to yaitu halaman petunjuk penggunaan aplikasi.

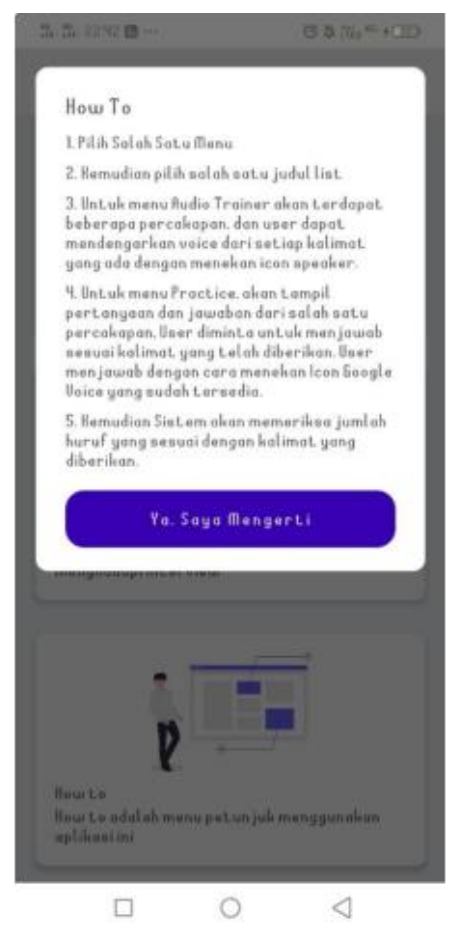

Gambar 9. Halaman How To

\section{6) Uji Coba Sistem}

Uji coba (Testing) pada aplikasi android Trainer wawancara pekerjaan dalam Bahasa Inggris menggunakan Audio Visual dengan pengujian Black box, yaitu pengujian tingkah laku yang lebih terfokus kepada kebutuhan fungsional dari perangkat lunak. Pengujian dilakukan dengan menjalankan sistem, kemudian melakukan penginputan data pada setiap menu. Hasil Black box Testing aplikasi ini berjalan dengan baik seperti pada Tabel 1 .

\section{TABEL 1. HASIL PENGUJIAN BLACK BOX}

\begin{tabular}{|c|c|c|c|c|}
\hline No & $\begin{array}{l}\text { Komponen } \\
\text { Yang Diuji }\end{array}$ & $\begin{array}{c}\text { Skenario } \\
\text { Pengujian }\end{array}$ & $\begin{array}{l}\text { Hasil Yang } \\
\text { Diharapkan }\end{array}$ & $\begin{array}{c}\text { Hasil } \\
\text { Pengujian }\end{array}$ \\
\hline \multirow{3}{*}{1} & \multirow{3}{*}{$\begin{array}{l}\text { Halaman } \\
\text { Utama }\end{array}$} & $\begin{array}{l}\text { Memilih Tombol } \\
\text { "Daftar" }\end{array}$ & $\begin{array}{l}\text { Menampilkan } \\
\text { halaman } \\
\text { register }\end{array}$ & Layak \\
\hline & & $\begin{array}{l}\text { Memilih Tombol } \\
\text { "Register" }\end{array}$ & $\begin{array}{l}\text { Menampilkan } \\
\text { halaman Login }\end{array}$ & Layak \\
\hline & & $\begin{array}{l}\text { Memiilih tombol } \\
\text { "login" }\end{array}$ & $\begin{array}{l}\text { Menampilkan } \\
\text { halaman menu }\end{array}$ & Layak \\
\hline \multirow[t]{3}{*}{2} & \multirow[t]{3}{*}{$\begin{array}{c}\text { Halaman } \\
\text { User }\end{array}$} & Memilih Logout & $\begin{array}{l}\text { Menampilkan } \\
\text { tampilan login }\end{array}$ & Layak \\
\hline & & $\begin{array}{l}\text { Memilih icon } \\
\text { "Audio Trainer ". }\end{array}$ & $\begin{array}{l}\text { Menampilkan } \\
\text { halaman Audio } \\
\text { Trainer }\end{array}$ & Layak \\
\hline & & $\begin{array}{l}\text { Memilih icon } \\
\text { "Practice" }\end{array}$ & $\begin{array}{l}\text { Menampilkan } \\
\text { halaman } \\
\text { Practice } \\
\end{array}$ & Layak \\
\hline \multirow[t]{6}{*}{3} & \multirow{6}{*}{$\begin{array}{l}\text { Halaman } \\
\text { Menu } \\
\text { Utama }\end{array}$} & $\begin{array}{l}\text { Memilih icon" } \\
\text { Tips" }\end{array}$ & $\begin{array}{l}\text { Menampilkan } \\
\text { halaman Tips }\end{array}$ & Layak \\
\hline & & $\begin{array}{l}\text { Memilih icon } \\
\text { "How To" }\end{array}$ & $\begin{array}{l}\text { Menampilkan } \\
\text { halaman How } \\
\text { To }\end{array}$ & Layak \\
\hline & & $\begin{array}{l}\text { Memilih icon" } \\
\text { user " }\end{array}$ & $\begin{array}{l}\text { Menampilkan } \\
\text { profile user }\end{array}$ & Layak \\
\hline & & $\begin{array}{l}\text { Memilih tombol “ } \\
\text { Greeting “ }\end{array}$ & $\begin{array}{l}\text { Menampilkan } \\
\text { tampilan } \\
\text { greeting }\end{array}$ & Layak \\
\hline & & $\begin{array}{l}\text { Memilih icon" } \\
\text { suara "pada } \\
\text { greeting }\end{array}$ & $\begin{array}{l}\text { Mengeluarkan } \\
\text { suara sesuai text }\end{array}$ & Layak \\
\hline & & $\begin{array}{l}\text { Memilih tombol “ } \\
\text { Greeting 2" }\end{array}$ & $\begin{array}{l}\text { Menampilkan } \\
\text { tampilan } \\
\text { greeting } 2\end{array}$ & Layak \\
\hline \multirow[t]{6}{*}{4} & \multirow[t]{6}{*}{$\begin{array}{l}\text { Halaman } \\
\text { Audio } \\
\text { Trainer }\end{array}$} & $\begin{array}{l}\text { Memilih icon" } \\
\text { suara pada } \\
\text { greeting } 2 \text { “ }\end{array}$ & $\begin{array}{l}\text { Mengeluarkan } \\
\text { suara sesuai text }\end{array}$ & Layak \\
\hline & & $\begin{array}{l}\text { Memilih tombol " } \\
\text { Greeting 3" }\end{array}$ & $\begin{array}{l}\text { Menampilkan } \\
\text { tampilan } \\
\text { greeting } 3 \\
\end{array}$ & Layak \\
\hline & & $\begin{array}{l}\text { Memilih icon" } \\
\text { suara " pada } \\
\text { greeting } 3\end{array}$ & $\begin{array}{l}\text { Mengeluarkan } \\
\text { suara sesuai text }\end{array}$ & Layak \\
\hline & & $\begin{array}{l}\text { Memilih tombol } \\
\text { "Greeting" }\end{array}$ & $\begin{array}{l}\text { Menampilkan } \\
\text { tampilan } \\
\text { practice } \\
\text { greeting } \\
\end{array}$ & Layak \\
\hline & & $\begin{array}{l}\text { Mrmilih tombol " } \\
\text { Next" }\end{array}$ & $\begin{array}{l}\text { Menampilkan } \\
\text { practice } \\
\text { greeting } \\
\text { selanjutnya } \\
\end{array}$ & Layak \\
\hline & & $\begin{array}{l}\text { Memilih icon “" } \\
\text { Recording” pada } \\
\text { greeting }\end{array}$ & Merekan Suara & Layak \\
\hline \multirow[t]{2}{*}{5} & \multirow[t]{2}{*}{$\begin{array}{l}\text { Halaman } \\
\text { Practice }\end{array}$} & $\begin{array}{l}\text { Memilih tombol } \\
\text { "Greeting 2" }\end{array}$ & $\begin{array}{l}\text { Menampilkan } \\
\text { tampilan } \\
\text { practice } \\
\text { greeting } 2\end{array}$ & Layak \\
\hline & & $\begin{array}{l}\text { Memilih tombol “ } \\
\text { Next” }\end{array}$ & $\begin{array}{l}\text { Menampilkan } \\
\text { tampilan } \\
\text { practice } \\
\text { greeting } 2 \\
\text { selanjutnya }\end{array}$ & Layak \\
\hline
\end{tabular}




\begin{tabular}{|c|c|c|c|c|}
\hline No & $\begin{array}{l}\text { Komponen } \\
\text { Yang Diuji }\end{array}$ & $\begin{array}{c}\text { Skenario } \\
\text { Pengujian }\end{array}$ & $\begin{array}{l}\text { Hasil Yang } \\
\text { Diharapkan }\end{array}$ & $\begin{array}{c}\text { Hasil } \\
\text { Pengujian }\end{array}$ \\
\hline & & $\begin{array}{l}\text { Memilih tombol } \\
\text { "Greeting 3" }\end{array}$ & $\begin{array}{l}\text { Menampilkan } \\
\text { tampilan } \\
\text { practice } \\
\text { greeting } 3 \\
\end{array}$ & Layak \\
\hline & & $\begin{array}{l}\text { Memilih tombol “ } \\
\text { Next }\end{array}$ & $\begin{array}{l}\text { Menampilkan } \\
\text { tampilan } \\
\text { practice } \\
\text { greeting } 3 \\
\text { selanjutnya }\end{array}$ & Layak \\
\hline & & $\begin{array}{l}\text { Memilih icon } \\
\text { "recording" pada } \\
\text { greeting } 2\end{array}$ & $\begin{array}{l}\text { Merecam suara } \\
\text { pengguna }\end{array}$ & Layak \\
\hline & & $\begin{array}{l}\text { Memilih icon } \\
\text { "recording" pada } \\
\text { greeting } 3\end{array}$ & $\begin{array}{l}\text { Merecam suara } \\
\text { pengguna }\end{array}$ & Layak \\
\hline & & $\begin{array}{l}\text { Memilih tombol } \\
\text { "Tips 1" }\end{array}$ & $\begin{array}{l}\text { Menampilkan } \\
\text { halaman tips } 1\end{array}$ & Layak \\
\hline \multirow[b]{3}{*}{6} & \multirow[b]{3}{*}{$\begin{array}{l}\text { Halaman } \\
\text { Tips }\end{array}$} & $\begin{array}{l}\text { Memilih tombol } \\
\text { "Tips 2" }\end{array}$ & $\begin{array}{l}\text { Menampilkan } \\
\text { halaman tips } 2\end{array}$ & Layak \\
\hline & & $\begin{array}{l}\text { Memilih tombol } \\
\text { "Tips 3" }\end{array}$ & $\begin{array}{l}\text { Menampilkan } \\
\text { halaman tips } 3\end{array}$ & Layak \\
\hline & & $\begin{array}{l}\text { Memilih tombol } \\
\text { "Tips 4" }\end{array}$ & $\begin{array}{l}\text { Menampilkan } \\
\text { halaman tips } 4\end{array}$ & Layak \\
\hline 7 & $\begin{array}{l}\text { Halaman } \\
\text { How To }\end{array}$ & $\begin{array}{l}\text { Memilih tombol " } \\
\text { Ya, saya mengerti }\end{array}$ & $\begin{array}{l}\text { Kembali ke } \\
\text { Menu Utama }\end{array}$ & Layak \\
\hline
\end{tabular}

Aplikasi android trainer wawancara pekerjaan dalam bahasa inggris menggunakan audio visual telah berhasil dijalankan pada platform android. Aplikasi ini dirancang menggunakan software perancangan android studio dengan menggunakan media audio visual sehingga pengguna bisa mendengarkan unsur suara dan gambar pada aplikasi ini, Dengan didukung oleh voice recognition yaitu sistem yang dapat mengidentifikasi seseorang melalui suara. Pada smartphone android terdapat sebuah aplikasi yang dikenal dengan automatic speech recognition yang berfungsi untuk memanfaatkan suara sebagai alat masukan dalam melakukan suatu proses. Automatic speech recognition terdiri dari dua macam yaitu speech to text yang merubah kata menjadi teks dan text to speech merubah teks menjadi suara.

\section{PENUTUP}

Aplikasi Android Trainer yang dibuat menggunakan software android studio dan mengggunakan teknologi seperti Voice Recognition dan google search API yaitu text to speech dan speech to text dikemas menggunakan Audio Visual dengan menampilkan suara dan gambar sehingga membuat proses penyampaian menjadi lebih mudah dan praktis, selain itu aplikasi android trainer dapat menjadi media pelatihan mandiri yang bisa digunakan kapan pun dan dimana saja dengan menggunakan smartphone android. Aplikasi android trainer yang dibuat berjalan dan berfungsi $100 \%$ pada smartphone Android. Saran Untuk penelitian berikutnya disarankan Trainer android ini menjadi suatu aplikasi multimedia wawancara yang lebih interaktif. Aplikasi android trainer ini selain untuk wawancara pekerjaan juga bisa dikembangkan menjadi aplikasi untuk Latihan/Trainer Penerapan Bahasa Inggris dibidang lainnya.

\section{REFERENCES}

[1] Y. Ningsih and N. Mariyati, "Pelatihan English Job Interview Bagi Komunitas Jember Banget Menggunakan Media Pembelajaran Video Tutorial," in Seminar Nasional Hasil pengabdian Kepada Masyarakat, 2017, pp. 278-282, [Online]. Available: https://publikasi.polije.ac.id/index.php/prosiding/article/view/734.

[2] I. D. A. Azir, "English for Jobseekers: Pelatihan Keterampilan BerBahasa Inggris untuk Anak Muda Pencari Kerja di Rumah Siap Kerja Jakarta," J. Surya Masy., vol. 2, no. 1, p. 20, 2019, doi: 10.26714/jsm.2.1.2019.20-28.

[3] E. Oktivera and F. A. W. Wirawan, "Program Peningkatan Kemampuan Komunikasi dalam Menghadapi Wawancara Kerja,” J. Karya untuk Masy., vol. 1, no. 1, pp. 43-49, 2020, [Online]. Available: http://www.jurnal.stiks-

tarakanita.ac.id/index.php/JKuM/article/view/302/187.

[4] J. Jefrizal, J. Jaroji, and A. Tediyana, “Aplikasi English Teacher Sebagai Alat Bantu Belajar English Conversation Berbasis Android dengan Menerapkan Voice Recognition," INOVTEK Polbeng - Seri Inform., vol. 2, no. 2, p. 105, 2017, doi: 10.35314/isi.v2i2.197.

[5] Iulia Stanica; Maria-Iuliana Dascalu; Constanta Nicoleta Bodea; Alin Dragos Bogdan Moldoveanu, "VR Job Interview Simulator: Where Virtual Reality Meets Artificial Intelligence for Education," in 2018 Zooming Innovation in Consumer Technologies Conference (ZINC), 2018, pp. 9-12, doi: 10.1109/ZINC.2018.8448645.

[6] S. Handayani, "Pentingnya Kemampuan BerBahasa Inggris Sebagai Dalam Menyongsong Asean," Ikatan Sarjana Pendidikan Indonesia (ISPI) Jawa Tengah, vol. 3, no. 1, pp. 102-106, 2016.

[7] Yayuk Widiyarti, "Mengenal 8 Macam Wawancara Kerja," Bisnis.com, 2019.

[8] D. Karyaningsih and P. Siswanto, "Rancang Bangun E-Learning Pronounciation Bahasa Inggris STKIP Setiabudhi Rangkasbitung Berbasis Web," J. Sisfokom (Sistem Inf. dan Komputer), vol. 9, no. 2, pp. 236-241, 2020, doi: 10.32736/sisfokom.v9i2.907.

[9] Gilang Ramdhani Putra, "Rancang Bangun Sistem Informasi Geografis Untuk Pemetaan Lokasi Wisata Alam Dengan Menggunakan Metode Prototyping Berbasis Mobile (Studi Kasus: Pulau Lombok) Rancang Bangun Sistem Informasi Geografis Untuk Pemetaan Lokasi Wisata Alam Dengan Menggunakan Me," Universitas Mataram, 2020.

[10] W. E. Susanto, Y. Galuh, and A. Astuti, "Perancangan E-Learning Berbasis Web Pada SMP Negeri 3 Patuk Gunungkidul Yogyakarta," J. Bianglala Inform., vol. 5, no. 2, 2017, [Online]. Available: https://ejournal.bsi.ac.id/ejurnal/index.php/Bianglala/article/view/2806.

[11] D. Siregar, M. E., Anyangsen, "Aplikasi Game Edukasi Belajar Menghafal Huruf dan Angka Berbasis Android dengan Metode Prototype Master Edison Siregar 1," J. Inov. Inform., vol. IV, no. 2, pp. 1-8, 2019, [Online]. Available: http://jurnalpradita.com/index.php/jii/article/view/93. 